\title{
Bogus neurosurgeon beats system hands down
}

The Health Professions Council of South Africa (HPCSA)'s top management has ordered a probe of all foreign-qualified specialist registrations going back at least a decade, and instituted a 'double verification' mechanism for all future such applications following a dramatic system failure.

The lack of diligent administrative checks (either due to collusion with the applicant or alarming dysfunction) during internal pre-registration procedures misled the PostGraduate Education and Training Committee (PGETC) for Medicine into registering a bogus neurosurgeon. Nyunyi Katumba of the Democratic Republic of Congo (DRC) practised as a neurosurgeon (albeit for two years under probation) in three Gauteng hospitals for nearly four years from 2007 after the HPCSA's registration system failed in its primary gatekeeper mission to protect patients. There are (so far) no reports of his having caused harm to patients, in spite of having independently handled several trauma cases and leading at least two major procedures under supervision at the Medunsa-linked Dr George Mukhari Hospital. A January 2009 report requested from the then Medunsa senior specialist, Professor Patrick Lekgwara, shows that Katumba took part in 48 procedures on adults (28 of them major cerebral) and nine on children (seven major cerebral). He also later conducted procedures independently while in private solo sessional practice at the Mediclinic Medforum in Gauteng.

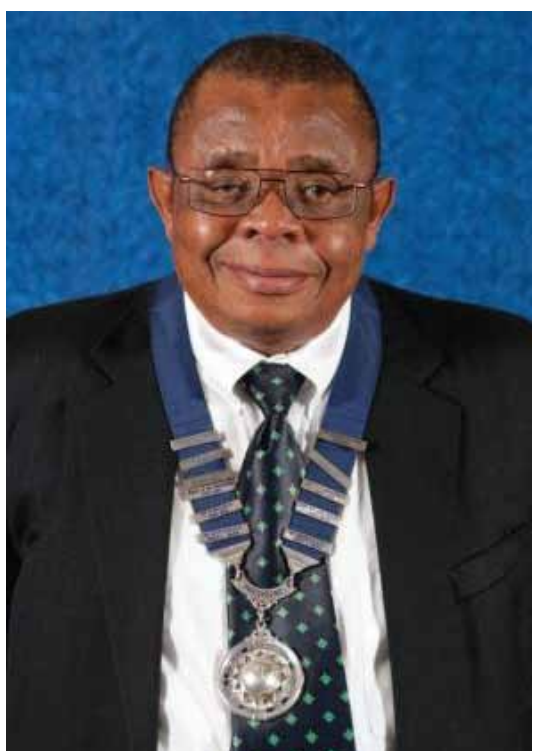

Professor Sam Mokgokong, President of the Health Professions Council of South Africa (HPCSA).
Of Katumba's official registration as a neurosurgeon, the HPCSA's Acting Registrar and CEO, Dr Kgosi Letlape, told Izindaba that Katumba 'received assistance, either due to incompetence or he reached people; all we know is the board (Medical and Dental Professions Board (MDPB), which the PGETC serves) was given false information' The HPCSA's President, Professor Sam Mokgokong, added, 'The biggest worry is that we have to check all the other foreignqualified doctors. We'd be naïve to assume it's a once-off thing. From 2010/2011, when Dr Letlape and I took over until today, many of these doctors are still working. The CEO has to get serious and heads have to roll.

A January 2009 report requested from the then Medunsa senior specialist, Professor Patrick

Lekgwara, shows that Katumba took part in 48 procedures on adults (28 of them major cerebral) and nine on children (seven major cerebral).

Bottleneck will strangle rural placement - rural health advocates

The severe tightening of what are necessary but already lengthy bureaucratic preregistration procedures for foreign-qualified doctors will dramatically slow down vital postings of this critical cadre to rural hospitals unpopular with local doctors. Healthcare delivery will inevitably suffer because these hospitals, some of which this year received no community service doctors (or less than their usual meager allocation), depend on foreign-qualified and community service doctors.

Both Letlape and Mokgokong, the latter an acclaimed neurosurgeon who ironically was Katumba's (highly skeptical) supervisor during most of his probation, said that because of previous fraudulent registrations of foreign-qualified doctors a comprehensive retrospective audit of 'at least 10 years' would now take place. The other precautionary measure was that in future all specialist applications by foreign-qualified practitioners will have to be approved by the professional board manager, the registrations manager and Dr Letlape. Letlape and Mokgokong initially suspected there was a link to previous fraudulent registrations. The Council's long-serving communications head, Mrs Bertha Peters-Scheepers, however said this was improbable, given that the only case on record took place between three and seven years earlier. This involved 11 foreign-qualified doctors fraudulently registered between 2000 and 2004. An internal disciplinary hearing and a criminal trial found the committee co-ordinator, Mrs Ntombi Ramatlo (who has since died), guilty of eight of these 11 counts. She was given the option of a jail term or fine and chose the latter. Katumba's bogus registration came in 2007 and 'nothing was found to link Ramatlo to him'

\section{Three council staffers questioned}

Three internal HPCSA staffers, whose signatures were on documentation involving Katumba, were currently being questioned, 'but at this stage we cannot confirm whether there was intent or not', Peters-Scheepers added.

Izindaba established that as far back as 2004 the PGETC ratified Katumba's first application (based on papers depicting him as having qualified as a doctor in the DRC and a neurosurgeon in Belgium), routinely stipulating that he write the local Colleges of Medicine neurosurgery exam which he failed. Ratification of obligatory documentation is unlikely without sophisticated forgery and/or internal administrative collusion. Letlape said both the manager and co-ordinator of the MDPB at the time 'have left us and we're seeking that information from them'. He said one had retired and the other 'gone on to a better job', both having left with clean records Mokgokong added: 'We can't just assume that this was the only case. It's just lucky that Katumba went through a public tertiary institution where we have the ultimate checks and balances (probation/supervision).'

\section{Three internal HPCSA} staffers, whose signatures were on documentation involving

Katumba, were currently

being questioned, 'but at this stage we cannot confirm whether there was intent or not,' Peters-Scheepers added.

In 2005 Katumba re-applied to the HPCSA, this time for registration as a GP, producing evidence that he sat for the obligatory local exam, but lacking pass or fail verification. The missing documentation was rendered irrelevant by the official moratorium on 


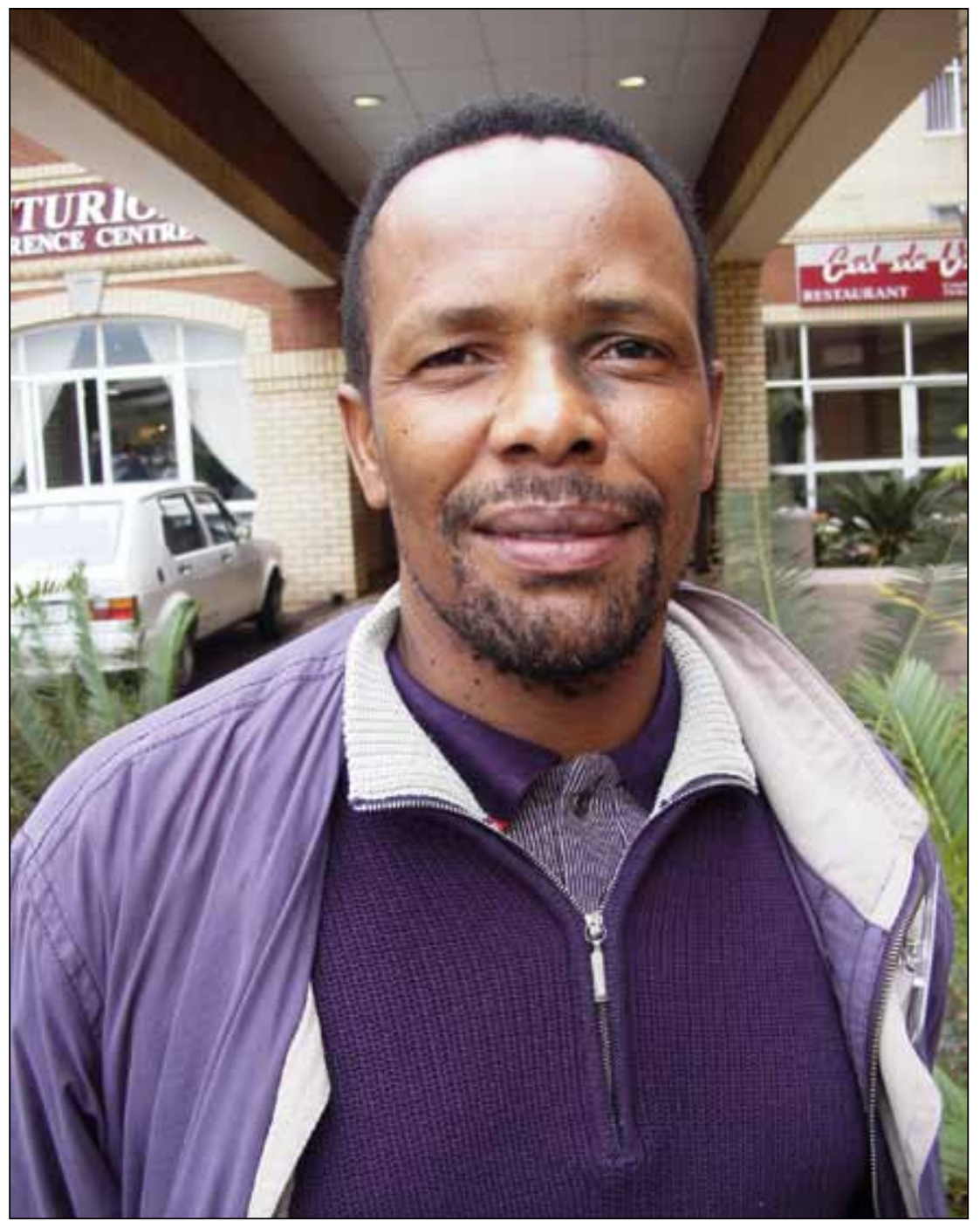

Dr Kgosi Letlape, Acting Registrar and CEO of the HPCSA.

hiring doctors from other African countries (which requires ministerial exemption). $\mathrm{He}$ was however correctly verified as having qualified as a GP in Kinshasa (DRC).

\section{Letlape said that besides any} supervisory issues, what was clear was that 'If we'd done our job properly he'd never have been employed anywhere - that's what Council takes responsibility for'.

Asked to explain how, once he finally got past the PGETC, Katumba remained on neurosurgical probation for two years without being fired, Mokgokong said the committee ordered one year, but the CEO of Steve Biko Academic Hospital, Dr Ernest Kenoshi, took into account more favourable progress reports by Professor Lekgwara and extended it by a year. Mokgokong emphasised: 'My [three-monthly] progress 'which basically won him the case at the CCMA [unfair dismissal] - even the registrars were surprised at his opinion'. Lekgwara responded that he was in a better position than Mokgokong to evaluate Katumba. 'He never even operated with him once here'. He (Lekgwara) had accepted 'a very personable, pleasant and eager to learn' Katumba at face value, knowing nothing about his background and training, but noticing that his surgical skills were poor. He recommended that Katumba be employed permanently, but as a research chief in an academic institution, with further evaluation by Mokgokong at Steve Biko Hospital 'if deemed necessary'.

Lekgwara's report reveals that Katumba assisted him in 40 major operations and accompanied his registrars on ward rounds. 'I concentrated asking questions of my registrars, not the "qualified" neurosurgeon. I didn't even know what his CV was. When I asked about his lack of surgical skills, he said that in Belgium there was not much opportunity to operate. My registrars complained that I was giving him more cases, so I began to concentrate more on them. I had no problem with him assisting and was quite surprised when it came out that he was a bogus surgeon. We were all fooled. He talked the talk. By the time he finished he had put eight papers of general neurosurgical material on my desk [presumably explaining the recommendations].' Lekgwara admitted that he 'became close' to Katumba, 'but I realised that something was not right'.

'What puzzled us at the time was why [Mokgokong] initially transferred a junior specialist [one Dr T Moya] to Steve Biko Academic Hospital to "stabilise the department there" instead of a senior specialist [Katumba].' He said Moya and he were 'victims of a decision we were never part of'. what Council takes responsibility for'. Both Council chiefs bemoaned the 'employeefriendly' Council for Conciliation, Mediation and Arbitration (CCMA), which ruled in favour of Katumba after Kenoshi eventually fired him in the interests of patient safety. Letlape remarked that 'to try and get rid of somebody who is incompetent is not easy in this country'. Katumba returned to Steve Biko Hospital after his CCMA victory, demanding Mokgokong reinstate him, but hit a brick wall. (Mokgokong initially supervised Katumba at Medunsa, leaving him with Lekgwara for several months when Mokgokong was appointed Head of Neurosurgery at Steve Biko Hospital.)

Mokgokong said he was 'still amazed' at Lekgwara's favourable reports on Katumba

\section{Undeterred by sacking - continues practising}

After his sacking from Steve Biko Hospital (where he had finally joined Mokgokong), Katumba continued working as a neurosurgeon, this time in Chris Hani Baragwanath Hospital's ICU, where a dire lack of such skills facilitated a speedy appointment. However, in August 2010 the rueful ICU chief called Mokgokong saying she doubted his competence as a doctor, never mind as a neurosurgeon, prompting the MDPB probe that led to his de-registration. Katumba was at the time also doing session work at the private Mediclinic Medforum (he used different referees to secure both 
jobs). Medforum hospital manager, Joey le Roux, said Katumba spent a year in rooms there, performing 'some surgeries, though very few'

Dr Saul Kornik of African Health Placements, an NGO that recruits healthcare workers for rural and underserved areas, pleaded for Council 'not to over-react and exclude hundreds of doctors who want to work here. Kornik said it took six months or more for well-qualified foreign doctors from the 'non-exam' track category of countries to be registered, let alone those in Katumba's category. Marije Versteeg of the Rural Health Advocacy Project warned that foreignqualified doctors would take their skills elsewhere in the world if they felt unwanted in South Africa. 'It is [already] taking way too long for a placement to happen and we're competing with many other countries desperate for human resources', she stressed.

Letlape responded, 'In the past things were done for expediency, so now if it takes 10 years [to register a doctor] that is how long it takes and if it takes three months, that's how long it takes. He claimed delays in registering doctors were due to noncompliance with the HPCSA process by applicants and not because of Council inefficiency.

\section{Kornik said it took six months or more for well-qualified foreign doctors from the 'non-exam' track category of countries to be registered, let alone those in Katumba's category. Marije Versteeg of the Rural Health Advocacy Project warned that foreign-qualified doctors would take their skills elsewhere in the world if they felt unwanted in South Africa.}

Mokgokong openly admitted to being 'embarrassed' by the controversy, but said the public could take comfort in Katumba being 'unable to jump the hurdle' of compulsory public sector supervisory probation. 'We have to remove people who collude from within [Council]. They will break even the safest security system. Those sitting on the PGET committee are academics of the highest standing, but their decisions are

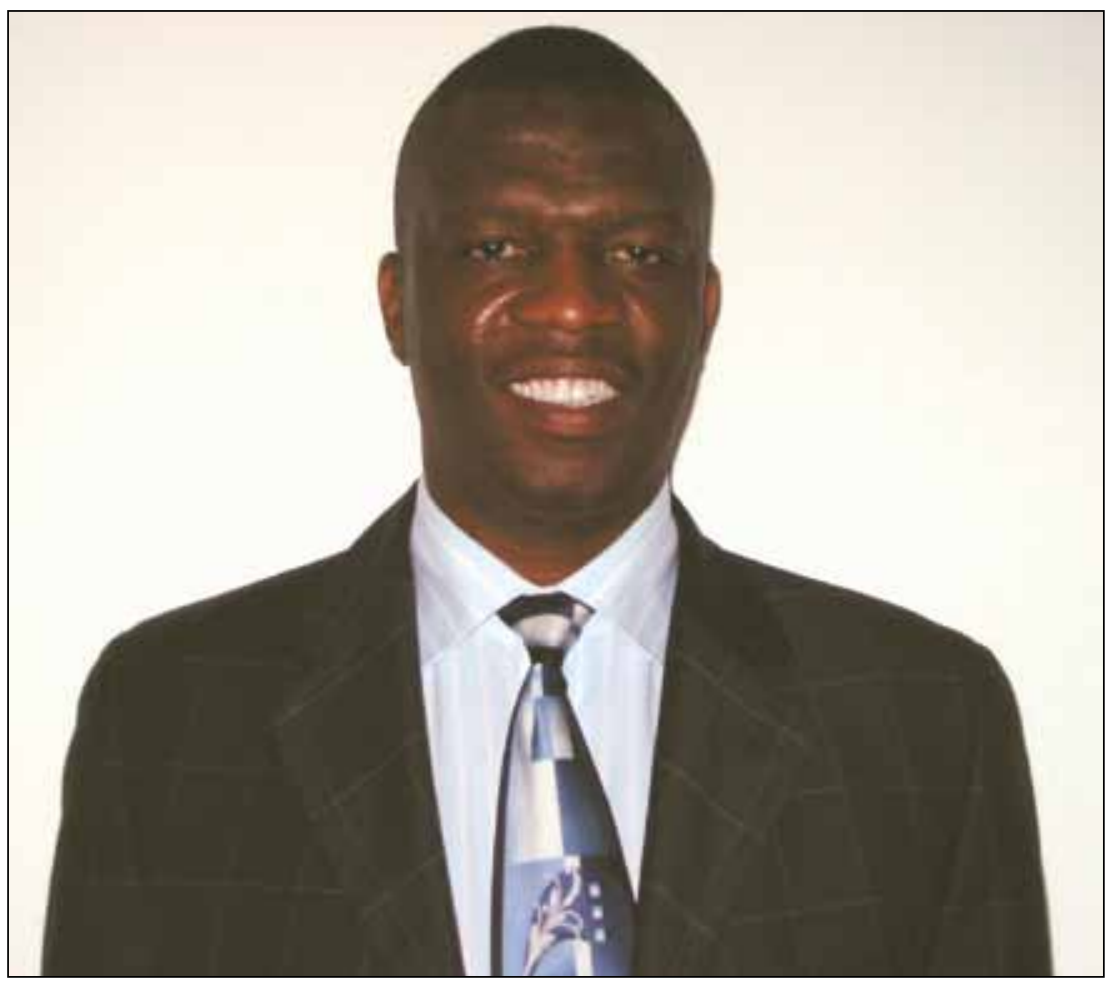

Professor Patrick Lekgwara, Principal Neuro-surgeon at Medunsa’s Gauteng campus.

based on the integrity of the information they receive.'

This January, South Africa's Department of Home Affairs withdrew Katumba's critical skills-based permanent residence, effectively deporting him.

- In July 2009, a long-standing senior and pivotal National Department of Health $(\mathrm{NDOH})$ player in its Foreign Workforce Management Programme (FWMP), SeanAllen Smith, was sacked for allegedly taking kickbacks to place foreign-qualified doctors. At the time Advocate Thomas Ngake, Director of Employee Relations, Equity and Wellness in the $\mathrm{NDOH}$, spoke breathlessly of a shady 'web' reaching into Home Affairs, the HPCSA and the FWMP. He described the matter as 'very sensitive' with 'serious political implications that involve management and beyond'. Ngake said that Smith's in camera internal disciplinary hearing followed a forensic probe, 'dating back over several years'. Attempts by Izindaba, citing overwhelming public interest, to try to obtain copies of the evidence were stonewalled. Private recruiting agencies for both doctors and nurses sang the praises of Smith in helping them cut red tape and place critically needed staff in spite of his own FWMP being severely understaffed. Well known to Izindaba, Smith was viewed by some insiders as 'a bit of a loose cannon', but foreign doctors cited him as the biggest single factor in their placement and ironing out of subsequent housing, subsidy and administrative problems. The $\mathrm{NDOH}$ has yet to answer a detailed list of Izindaba questions faxed and e-mailed to Ngake and two senior communications officers on 27 July 2009. ${ }^{2}$ These and copies of the internal enquiry would, among other things, have established what impact Smith's sacking and subsequent precautionary measures had on foreign doctor placement and perhaps thrown light on the current controversy. Mokgokong requested Izindaba's reportage of Smith's sacking for inclusion in the Council probe.

\section{Chris Bateman}

chrisb@hmpg.co.za

\footnotetext{
1. Bateman C. Rural health care delivery set to collapse. S Afr Med

J 2006;96:1219-1226.
2. Bateman C. Veil of silence falls over health department kickback probe. S Afr Med J 2009; 99:626-627.
} 